BANGLADESH JOURNAL OF SCIENTIFIC AND INDUSTRIAL RESEARCH

E-mail: bjsir07@gmail.com

\title{
Antioxidant activities of $Z$. officinale Roscoe and $A$. allughas Roscoe (Zingiberaceae) Rhizomes
}

\author{
N. A. Sattar, F. Hussain* and T. Iqbal \\ Department of Chemistry and Biochemistry, Faculty of Sciences, University of Agriculture, Faisalabad-38040, \\ Pakistan
}

\begin{abstract}
Ginger (Zingiber officinale Roscoe) and Lachii (Alpinia allughas Roscoe) are well known and widely used herbs. Ethanol, acetone, methanol and n-hexane extracts of Zingiber officinale Roscoe and Alpinia allughas Roscoe roots were screened for their antioxidant activities in an effort to compare and validate the medicinal potential of their subterranean part. Total phenol (mg gallic acid/g dry matter) and flavonoid contents (catechin equivalents/g dry matter) were estimated by Folin-Ciocalteu and aluminium chloride colorimetric tests respectively. Radical scavenging activity by DPPH methods was expressed as percent inhibition. Total phenolic contents varied from $10 \pm 0.12$ to $14 \pm 0.03 \mathrm{mg}$ gallic acid/g for Z. officinale and $5.46 \pm 0.02$ to $12.9 \pm 0.06 \mathrm{mg}$ gallic acid/g for A. allughas. Total flavonoids were $5.33 \pm$ 0.75 to $8.34 \pm 2.1 \mathrm{mg}$ catechin/g for Zingiber officinale and $1.50 \pm 0.447$ to $9.92 \pm 2.5 \mathrm{mg}$ catechin/g for Alpinia allughas in four solvents. Maximum phenolic and flavonoid contents were observed in methanol extracts. The antioxidant activity (percent inhibition) of Zingiber officinale and Alpinia allughas ranged from 26.8 to 68.3 and 14.3 to 58.5 respectively in different solvents. Overall, the findings indicate that the both spices are good sources of phytochemicals which could be exploited as great potentials for drugs and/or nutritional supplements.
\end{abstract}

Keywords: Zingiber officinale; Alpinia allughas; Phenols; Flavonoids; Rhizomes

\section{Introduction}

Free radicals and reactive oxygen species generated during metabolic functions can damage DNA, lipids and proteins. The efficacy of antioxidant defense repair systems to scavenge and minimize the formation of reactive oxygen species can be enhanced by plant derived antioxidants. Phytotherapy is of significant attention as natural antioxidants could be promising agents for management of oxidative stress-related diseases (Kar et. al., 1999).

Numerous species of Zingiberaceae family exhibit antioxidant, antimicrobial and cytotoxic activities and are subjected to pharmacological research (Ghasemzadeh et. al., 2010; Priya et. al., 2011; Lu et. al., 2012; Rani et. al., 2012). Among these, most interesting are Zingiber officinale and Alpinia allughas whose wild rhizomes are used as traditional medicines and spices by the local population. Zingiber officinale (ginger) rhizome is used as a spice. Alpinia allughas (Lachii) rhizome has numerous essential oils and is a therapeutic supplement in folk medicine for gout and colic diseases (Prakash et. al., 2007; Nanasombat et. al., 2009; Sharma et. al., 2011). In present study, antioxidant compo- nents and activities of Zingiber officinale and Alpinia allughas rhizomes (root) in four solvent were assessed.

\section{Material and method}

\section{Plant material and extract preparation}

All the plants were collected from the local retail markets of Faisalabad, Pakistan. About $250 \mathrm{~g}$ of the root parts of the plants were cut into smaller pieces and air-dried under the shade. The materials were then extracted with ethanol, acetone, methanol and n-hexane. Extracts of each solvent were evaporated under reduced pressure and the final residues were used for the bioassays.

\section{Determination of Total Phenolic Contents}

Total phenol contents (TP) were estimated using FolinCiocalteu assay as described previously (Duarte-Almeida et. al., 2006) with slight modifications. Briefly, extract was dissolved in $1 \mathrm{~mL}$ dimethyl sulfoxide (DMSO) and $1 \mathrm{~mL}$ of $10 \%$ dilution of Folin- Ciocalteu reagent. After 3 minutes, 3 $\mathrm{mL}$ of $\mathrm{Na}_{2} \mathrm{CO}_{3}(1 \% \mathrm{w} / \mathrm{v})$ was added and the resulting mix-

*Corresponding author. e-mail: fatmauaf@yahoo.com 
ture was incubated at room temperature for 2 hours. The absorbance of all the samples was measured at $760 \mathrm{~nm}$ and results were expressed in terms of gallic acid equivalent $(\mathrm{mg}$ gallic acid/g dry matter).

\section{Determination of Total Flavonoid Contents}

Aluminium chloride colorimetric technique was used for total flavonoid contents (TF) estimation. Each extract (0.5 $\mathrm{mL}$ of $1: 10 \mathrm{~g} / \mathrm{mL}$ ) was mixed with $1.5 \mathrm{~mL}$ of respective solvent, $0.1 \mathrm{~mL}$ of $10 \%$ aluminium chloride, $0.1 \mathrm{~mL}$ of $1 \mathrm{M}$ potassium acetate and $2.8 \mathrm{~mL}$ of distilled water. The absorbance was measured at $510 \mathrm{~nm}$ and $\mathrm{TF}$ concentrations were articulated as catechin equivalents/g dry matter (Siddique et. al. 2010).

\section{Determination of Antioxidant activities}

Radical scavenging activity by DPPH (2, 2-diphenyl-1picrylhydrazyl)

The DDPH assay was carried out as described by Souri et. al. (2008). The antioxidant activity of extracts was assessed by measuring their scavenging abilities to 2, 2-diphenyl 1-11-picrylhydrazyl stable radical. $50 \mathrm{uL}$ aliquot of various concentrations of the samples was added to $5 \mathrm{~mL}$ of a $0.004 \%$ methanol solution of DPPH. After 30 minutes incubation period at room temperature, the absorbance was read against a blank at $517 \mathrm{~nm}$. Percent inhibition was calculated as; I $\%=($ A blank-A sample $/$ A blank $) \times 100$

Where A blank is the absorbance of the control reaction (containing all reagents except the test compound) and A sample is the absorbance of the test compound.

\section{Statistical analysis}

All data were expressed as mean \pm S.D of triplicate measurement. To find the optimum antioxidant activity and significant difference between variables, Students t-test, tukey B test and ANOVA were performed using the Statistical Package for the Social Sciences (SPSS Inc. Chicago, IL,
USA) software, (version 15.0). A $p$-value of less than 0.05 is considered statistically significant.

\section{Results and discussion}

\section{Total Phenolic Contents}

The medicinal properties of Zingiberaceae family are due to the presence of certain bioactive compounds having antioxidant activities (Bak et. al., 2012). The levels of phenolic compounds in various solvents are presented in Table I. TP were determined using the Folin-Ciocalteu reagent and expressed as gallic acid equivalents (GAE) per gram. The Follin-Ciocalteu method was selected because of its high intensity, quick results and low interference (Sultana et. al., 2010).

Antioxidant activities of plant extracts are usually linked to their phenolic content. The high potential of phenolics to scavenge free radicals may be due to many phenolic hydroxyl groups they possess (Atmani et. al., 2009). Hinneburg et. al. (2006) found the total phenolic content of aqueous ginger extract to be $23.5 \mathrm{mg}$ gallic acid/g of sample. In our study, $\mathrm{TP}$ varied from $10 \pm 0.12$ to $14 \pm 0.03 \mathrm{mg} \mathrm{GAE}$ per gram for $Z$. officinale. These results were in accordance with previously reported $10.22 \pm 0.87-13.5 \pm 2.26 \mathrm{mg}$ GAE per gram TPCs in Malaysian ginger varieties (Ghasemzadeh et. al., 2010). Shirin and Prakash (2010) determined $510 \pm 2.2$ (methanol), $565 \pm 4.1$ (ethanol) and $325 \pm 1.9$ (acetone) TP as $\mathrm{mg}$ of Tannic acid equivalents (TAE) $/ 100 \mathrm{~g}$ of sample in ginger roots. TP in $Z$. officinale were higher than $A$. allughas. For $A$. allughas, TP in present study varied from $5.46 \pm 0.02$ to $12.9 \pm 0.06 \mathrm{mg}$ GAE per gram in four solvents. Literature reports no studies on antioxidant potential of $A$. allughas.

The difference in TP of Z.officinale and A. allughas was significant $(p<0.05)$ in acetone extracts and maximum TP were observed in methanol extracts as compared to all other solvents. Methanol has been proven most effective solvent to determine antioxidants. The efficiency of methanol as solvent to get better and much quantity of phenolic contents

Table I. Antioxidant components of $Z$. officinale and $A$. allughas rhizomes in different solvent extracts

\begin{tabular}{lccccc}
\hline Antioxidant components & Specie & Methanol & Ethanol & Acetone & n-Hexane \\
\hline Total Phenolic Contents (TP) & Z. officinale & $14 \pm 0.03$ & $11.2 \pm 0.07$ & $10 \pm 0.12$ & $13.5 \pm 0.05$ \\
& A. allughas & $12.9 \pm 0.06$ & $10.3 \pm 0.06$ & $5.46 \pm 0.02$ & $11.0 \pm 0.06$ \\
Total Flavonoid Contents (TF) & Z. officinale & $8.34 \pm 2.1$ & $5.33 \pm 0.75$ & $5.95 \pm 0.46$ & $7.81 \pm 0.56$ \\
& A. allughas & $8.20 \pm 5.7$ & $1.92 \pm 0.014$ & $1.50 \pm 0.447$ & $9.92 \pm 2.5$ \\
\hline
\end{tabular}

All analyses are the mean of triplicate measurements \pm standard deviation. TP expressed as mg gallic acid/g dry material; TF expressed as catechin equivalents/g dry material 
may be due to different reasons; changed climate, reagent efficacy, manual error and different quantity in reaction media. The methanol and n-hexane were found to be most effective solvents as compared to ethanol and acetone for total phenolics. The trend of phenolic contents in decreasing order was methanol $>\mathrm{n}$-hexane $>$ ethanol $>$ acetone. Applying tukey B test; there was no significance difference in TP contents among $\mathrm{n}$-hexane, acetone and ethanol.

\section{Total Flavonoid Contents}

The flavonoids function as metal chelators, reducing agents, chain-breaking antioxidants and quenchers of the formation of singlet oxygen (Ghimeray et. al., 2009). Flavonoids with hydroxyl groups are responsible for radical scavenging effect in plants (Ebrahimzadeh et. al., 2008). Total flavonoid contents were determined using the aluminium chloride colorimetric technique and expressed as expressed as $\mathrm{mg}$ quercetin/g of dry plant material. The TF varied from $5.33 \pm$ 0.75 to $8.34 \pm 2.1 \mathrm{mg}$ catechin/g for Zingiber officinale and $1.50 \pm 0.447$ to $9.92 \pm 2.5 \mathrm{mg}$ catechin/g for Alpinia allughas (Table I). Similar to our results, $3.66 \pm 0.45$ and $4.21 \pm 0.98$ $\mathrm{mg}$ quercetin/g plant materials $\mathrm{TF}$ were observed in some varieties of Zingiber officinale Roscoe by Ghasemzadeh et. al. (2010). However, Shirin et. al. (2010) observed $0.249 \pm$ $0.002-0.685 \pm 0.005$ (g quercetin equivalents $/ 100 \mathrm{~g}$ plant material) TF in Zingiber officinale roots.

The difference of TF in Zingiber officinale and Alpinia allughas was significant in all the solvents. Similar to the phenolics results, maximum concentrations of total flavonoid in $Z$. officinale and $A$. allughas rhizomes were observed in methanol extracts as compared to all other solvents. It can be due to higher solubility of phenols and flavonoids in methanol. The trend of flavonoid contents in decreasing order was methanol $>\mathrm{n}$-hexane $>$ acetone >ethanol.

\section{Antioxidant Activities}

The DDPH assay was carried out as described by Souri et. al. (2008). The antioxidant activity of extracts was assessed by measuring their scavenging abilities to 2, 2-diphenyl 1-11-picrylhydrazyl stable radical. The DPPH is very stable free radical along deep violet color which gives maximum absorption within range of 515 to $528 \mathrm{~nm}$. When it loses its chromophore, its color becomes yellow. As the degree of hydroxylation of phenolic contents or the amount of phenolic contents elevated, the DPPH free radical scavenging ability is also enhanced (Nenadis et. al., 2002). Degree of discoloration indicates scavenging potential of the antioxidant extract which is due to the hydrogen donating or radical scavenging ability (Ajila et. al., 2007).
Table II. Antioxidant activity of $Z$. officinale and $A$. allughas rhizomes in different solvent extracts

\begin{tabular}{lcccc}
\hline Specie & \multicolumn{4}{c}{ Inhibition (\%) } \\
\cline { 2 - 5 } & Methanol & Ethanol & Acetone & n-Hexane \\
\hline Z. officinale & 68.3 & 27.2 & 26.8 & 49.2 \\
A. allughas & 58.5 & 14.3 & 20.2 & 36.5 \\
\hline
\end{tabular}

All 6 are the mean of triplicate measurements. Radical scavenging activity is expressed as percent of free radical inhibition

The antioxidant activity (percent inhibition) of Zingiber officinale and Alpinia allughas ranged from 26.8 to 68.3 and 14.3 to 58.5 respectively in different solvents (Table II). The difference in antioxidant activity between Zingiber officinale and Alpinia allughas was significant in all the solvents. Earlier, 51.41-58.22 \% inhibition was observed in methanolic extracts of Zingiber officinale rhizomes by Ghasemzadeh et. al. (2010).

The comparison between the solvents indicated quiet significant difference in antioxidant activity of methanol and nhexane. The trend of scavenging activity to the free radicals for Zingeber officinale was methanol $>\mathrm{n}$-hexane $>$ ethanol $>$ acetone. The trend in DPPH scavenging activity of $A$. allughas was methanol $>\mathrm{n}$-hexane $>$ acetone $>$ ethanol.

The activity of the extracts in the DPPH assay indicate their hydrogen-donating ability as the free radical are known to cause auto-oxidation of the unsaturated lipids in foods (Singh et. al., 2007). Oktay et. al. (2003) reported strong antioxidant activity of water and ethanol extracts of fennel seeds. The combined effect of solvents and different plants on radical scavenging activity is significant. As evident from the present data, methanol is most suitable solvent for getting maximum activity of scavenging free radicals.

\section{Conclusion}

The present study has provided some comparative information on the phytochemistry of $Z$. officinale Roscoe. and $A$. allughas Roscoe. available in local Pakistani markets. The investigation also indicates that the A. allughas, a less studied plant is one of the best sources for natural antioxidant. Further, there is a need to isolate and identify these natural antioxidant compounds present in $Z$. officinale and $A$. allughas.

\section{References}

Ajila CM, Naidu KA, Bhat SG, Prasada RUJS (2007), Bioactive compounds and antioxidant potential of 
mango peel extract, Food Chem. 105(3): 982-988.

Atmani D, Chaher N, Berboucha M, Ayouni K, Lounis H, Boudaoud H, Debbache N and Atmani D (2009), Antioxidant capacity and phenol content of selected Algerian medicinal plants, Food Chem. 112(2): 303309 .

Bak MJ, Ok S, Jun M and Jeong WS (2012), 6-shogaol-rich extract from ginger up-regulates the antioxidant defense systems in cells and mice, Molecules, 17(7): 8037-8055.

Duarte-Almeida JM, Novoa AV, Linares AF, Lajolo FM and Genovese MI (2006), Antioxidant activity of phenolics compounds from sugar cane (Saccharum officinarum L.) juice, Plant Food Hum. Nutr. 61(4):187-921.

Ebrahimzade MA, Pourmorad F and Hafezi S (2008), Antioxidant activities of Iranian corn silk. Turk. J. Biol. 32: 43-49.

Ghasemzadeh A, Jaafar HZE and Rahmat A (2010), Antioxidant activities, total phenolics and flavonoids content in two varieties of Malaysian young ginger (Zingiber officinale Roscoe). Molecules. 15: 43244333.

Ghimeray AK, Jin C, Ghimire BK and Cho DH (2009), Antioxidant activity and quantitative estimation of azadirachtin and nimbin in Azadirachta indica A. Juss grown in foothills of Nepal, Afr. J. Biotechnol. 8(13): 3084-3091.

Hinneburg I, Dorman HDJD and Hiltunen R (2006), Antioxidant activity of extracts from selected culinary herbs and spices, Food Chem. 97(1): 122-129.

Kar A, Choudhary BK and Bandyopadhyay NG (1999), Preliminary studies on the inorganic constituents of some indigenous hypoglycaemic herbs on oral glucose tolerance test, J. Ethnopharmacol. 64(2): 179-184.

Lu CL, Zhao HY and Jiang JG (2012), Evaluation of multiactivities of 14 edible species from Zingiberaceae. Int. J. of Food Sci. and Nutr. [Epub ahead of print (doi:10.3109/ 09637486.2012.694852].

Nanasombat S and Teckchuen N (2009), Antimicrobial, antioxidant and anticancer activities of Thai local vegetables, J. Med. Plants Res. 3(5): 443-49.
Nenadis N and Tsimidou M (2002), Observations on the estimation of scavenging activity of phenolic compounds using rapid 1,1-diphenyl-2-picrylhydrazyl (DPPHo) tests, J. Am. Oil Chem. Soc. 79(12): 1191-1195.

Oktay M, Gülçin I and Küfrevioglu OI (2003), Determination of in vitro antioxidant activity of fennel (Foeniculum vulgare) seed extracts. LWT - Food Sci. Technol. 36(2): 263-271.

Prakash O, Joshi S, Pant AK, Chanotiya CS and Mathela CS (2007), Volatile constituents of rhizomes and leaves of Alpinia allughas Roscoe, J. Essent. Oil Res. 19: 407-409.

Priya MR, Padmakumari KP, Sankarikutty B, Cherian OL, Nisha VM and Raghu KG (2011), Inhibitory potential of ginger extracts against enzymes linked to type 2 diabetes, inflammation and induced oxidative stress. Int. J. Food. Sci. Nutr. 62(2): 106-110.

Rani MP, Krishna MS, Padmakumari KP, Raghu KG and Sundaresan A (2012), Zingiber officinale extract exhibits antidiabetic potential via modulating glucose uptake, protein glycation and inhibiting adipocyte differentiation: an in vitro study. J. Sci. Food. Agr. 92(9): 1948-1955.

Sharma UK and Pegu S (2011), Ethnobotany of religious and supernatural beliefs of the mising tribes of Assam with special reference to the 'Dobur Uie'.

Shirin APR and Prakash J (2010), Chemical composition and antioxidant properties of ginger root (Zingiber officinale), J. Med. Plants. Res. 4(24): 2674-2679.

Siddique NA, Mujeeb M, Najmi AK and Akram M (2010), Evaluation of antioxidant activity, quantitative estimation of phenols and flavonoids in different parts of Aegle marmelos, Afr. J. Plant. Sci. 4(1):001-5.

Singh R, Singh S, Kumar S and Arora S (2007), Evaluation of antioxidant potential of ethyl acetate extract/fraction of Acacia auriculiformis A, Cunn. Food Chem. Toxicol. 45(7): 1216-1223.

Souri E, Amin G, Farsam H, Jalalizadeh H and Barezi S (2008), Screening of thirteen medicinal plants extracts for antioxidant activity, Iran. J. Pharm. Res. 7(2):149154.

Sultana S, Ripa FA and Hamid K (2010), Comparative antioxidant activity study of some commonly used spices in Bangladesh, Pak. J. Biol. Sci. 13(7): 340-343.

Received: 23 January 2013; Revised: 13 March 2013; Accepted: 21 May 2013. 